\title{
Program Kewirausahaan Pembuatan Hiasan Penjor: Pemberdayaan Ibu PKK Berbasis Kearifan Lokal
}

\author{
I Nyoman Kusuma Adnyana Mahaputra1, Ni Wayan Rustiarini'*, I Made Sudiana², Ni Putu Nita \\ Anggraini $^{3}$
}

${ }^{1}$ Program Studi Akuntansi, Universitas Mahasaraswati Denpasar, Jl. Kamboja No.11 A, Denpasar, Indonesia, 80233

${ }^{2}$ Program Studi Pendidikan Biologi, IKIP Saraswati, Jl. Pahlawan No. 2, Tabanan, Indonesia, 82113

${ }^{3}$ Program Studi Manajemen, Universitas Mahasaraswati Denpasar, Jl. Kamboja No.11 A, Denpasar, Indonesia, 80233

*Email Korespondensi: rusti_arini@unmas.ac.id

\begin{abstract}
Abstrak
Pemerintah Indonesia telah memfokuskan perhatian pada upaya pengentasan kemiskinan di daerah pedesaan. Kegiatan pengabdian ini memprioritaskan pembangunan sumber daya manusia bernilai ekonomi melalui program kewirausahaan di Desa Kaliakah dan Desa Baluk. Terdapat beberapa permasalahan yang dihadapi, seperti 1) rendahnya pengetahuan masyarakat mengenai wirausaha, 2) kurangnya motivasi untuk melakukan wirausaha, serta 3) rendahnya kreativitas untuk memulai wirausaha. Bertitiktolak dari permasalahan tersebut, program kewirausahaan ini direalisasikan dalam bentuk penyuluhan dan pelatihan "mejejahitan" hiasan penjor. Kegiatan ini bertujuan untuk meningkatkan pendapatan keluarga yang bermuara pada peningkatkan kesejahteraan masyarakat desa. Program ini sekaligus bermanfaat untuk melestarikan budaya Bali, khususnya dalam seni membuat hiasan penjor. Hasil evaluasi kegiatan menunjukkan bahwa mayoritas peserta menyatakan pelatihan ini menarik dan bermanfaat. Selain itu, peserta mampu memahami materi yang diberikan sehingga memiliki keinginan untuk menjadi wirausaha. Dengan demikian, pelaksanaan program kewirausahaan tidak hanya mampu mengurangi kemiskinan masyarakat desa namun juga mempertahankan kearifan lokal di desa tersebut.
\end{abstract}

Kata kunci: Kemiskinan; kewirausahaan; penjor; kearifan lokal

\begin{abstract}
The Indonesian government has focused attention on efforts to reduce poverty in rural areas. This service activity prioritizes the development of human resources with economic value through entrepreneurship programs in Kaliakah and Baluk Villages. There are several problems faced, such as 1) low public knowledge of entrepreneurship, 2) lack of motivation to do entrepreneurship, and 3) low creativity to start the entrepreneurship. Starting from these problems, this entrepreneurship program is realized in the form of counseling and training on "mejejaitan" penjor decoration. This activity aims to increase family income which leads to improving the welfare of rural communities. This program is also useful for preserving Balinese culture, especially in the art of making penjor decorations. The evaluation results of the activities indicated that the majority of participants stated this training interesting and useful. In addition, participants are able to understand the material provided so that they have a desire to become entrepreneurs. Therefore, the entrepreneurship programs implementation is not only to reduce poverty in rural communities but also maintain local wisdom in the village.
\end{abstract}

Keywords: Poverty; entrepreneurship; penjor; local wisdom.

Format Sitasi: Mahaputra, I. N. K. A., Rustiarini, N. W., Sudiana, I. M., \& Anggraini, N. P. N. (2020). Program Kewirausahaan Pembuatan Hiasan Penjor: Pemberdayaan Ibu PKK Berbasis Kearifan Lokal. Jurnal Solma, 09(2), 458-467. Doi: http://dx.doi.org/10.22236/solma.v9i2.5520

Diterima: 01 September 2020 | Revisi: 05 September 2020 | Dipublikasikan: 30 Oktober 2020


(C) 2020 Oleh authors. Lisensi Jurnal Solma, LPPM-Uhamka, Jakarta. Artikel ini bersifat open access yang didistribusikan di bawah syarat dan ketentuan Creative Commons Attribution (CC BY) license. (http://creativecommons.org/licenses/by/4.0/).

\section{PENDAHULUAN}

Beberapa tahun terakhir, pemerintah di negara-negara berkembang sibuk dengan upaya pengentasan kemiskinan, khususnya di daerah pedesaan. Pemerintah Indonesia pun telah memberikan perhatian yang besar terhadap program pembangunan desa, baik secara sektoral maupun regional. Salah satu pendekatan yang dianggap efektif untuk mengurangi kemiskinan melalui program kewirausahaan (Lee \& Rodríguez-Pose, 2020). Program ini tidak hanya menciptakan lapangan pekerjaan, namun juga meningkatkan pertumbuhan ekonomi masyarakat dan mendorong pembangunan berkelanjutan (Acs et al., 2005; Dhahri \& Omri, 2018; Gómez-Gras et al., 2010; Seuneke et al., 2013; Thurik et al., 2008).

Program kewirausahaan dalam kegiatan pengabdian ini diimplementasikan melalui pemberdayaan ibu-ibu PKK sebagai tulang punggung kedua dalam keluarga. Program ini menjadi bagian integral dari kegiatan ekonomi. Hasil riset empiris menunjukkan bahwa aktivitas kewirausahaan ibu-ibu rumah tangga berdampak positif terhadap pengurangan kemiskinan, khususnya di negara-negara berkembang (Bruton et al., 2013; Hoang et al., 2014; Tobias et al., 2013). Dapat dikatakan bahwa program kewirausahan tidak hanya menciptakan peluang kerja bagi diri mereka sendiri namun juga masyarakat desa lainnya (Carter et al., 2017; Peachey et al., 2014).

Dalam konteks daerah Bali, perempuan Bali yang tergabung dalam ibu-ibu PKK tidak hanya memiliki peranan sebagai seorang ibu yang mendidik anak dan mengurus rumah, juga berkiprah dalam aktivitas sosial kemasyarakatan dan keagamaan. Salah satu ketrampilan yang wajib dimiliki perempuan Bali adalah "mejejaitan". Kata mejejaitan dimaknai sebagai aktivitas menjahit janur atau ental (rontal) menjadi perlengkapan sesajen (banten) atau perlengkapan ritual lainnya (Indriani, 2019). Kegiatan mejejahitan tidak hanya untuk memenuhi kebutuhan persembahyangan keluarga namun dapat dijadikan sebagai industri kreatif rumah tangga, seperti membuat hiasan penjor. Program ini dilatarbelakangi pemikiran bahwa hiasan penjor merupakan kerajinan yang sering digunakan dalam upacara agama dan adat di Bali. Penjor juga dapat digunakan sebagai dekorasi untuk menyambut kunjungan pemerintah, atau menghormati tamu-tamu tertentu (Arjawa \& Jayantiari, 2020). Mengingat tingginya kebutuhan penggunaan penjor dalam berbagai kegiatan di Bali, program kewirusahaan pembuatan hiasan penjor dipandang penting untuk dilakukan, serta menghasilkan nilai ekonomi yang tinggi.

Program pengabdian masyarakat ini dilakukan di Desa Kaliakah dan Desa Baluk, Kabupaten Jembrana, Provinsi Bali. Pada tahun 2017, kedua desa ini menerima dana hibah program Gerbang Sadu Mandara dari Pemerintah Provinsi Bali. Program ini memfasilitasi pemerintah dan masyarakat desa dalam mengembangkan diri dan lingkungan secara aktif dan mandiri sehingga mempercepat penanggulangan kemiskinan di Propinsi Bali. Pada kegiatan pengabdian ini, Fakultas Ekonomi dan Bisnis Universitas Mahasaraswati Denpasar dan IKIP Saraswati Tabanan bekerjasama dengan Direktorat Jenderal Pendidikan Tinggi dan Pemerintah Daerah Kabupaten Jembrana melaksanakan kegiatan kewirausahaan bagi ibu-ibu PKK. Program kemitraan wilayan ini sekaligus menjadi upaya 
lanjutan untuk mendukung program pengentasan kemiskinan yang dicanangkan pemerintah daerah Propinsi Bali. Dengan demikian, pelaksanaan program kewirausahaan diharapkan mampu meningkatkan perekonomian masyarakat di kedua desa tersebut.

Program pengabdian ini memfokuskan pada pembangunan sumber daya manusia bernilai ekonomi. Tujuan program kemitraan wilayah ini adalah untuk meningkatkan pendapatan keluarga yang bermuara pada peningkatkan kesejahteraan masyarakat Desa Kaliakah dan Desa Baluk. Program ini sekaligus bermanfaat untuk melestarikan budaya Bali, khususnya dalam seni membuat hiasan penjor.

\section{MASALAH}

Berdasarkan hasil wawancara dan diskusi dengan para aparat pemerintah desa dan masyarakat, terdapat beberapa permasalahan yang dialami ibu-ibu PKK terkait dengan program kewirausahaan, yaitu: 1) rendahnya pengetahuan mengenai wirausaha, 2) kurangnya motivasi untuk melakukan wirausaha, dan 3) kurangnya kreativitas untuk memulai wirausaha. Solusi yang ditawarkan untuk mengatasi permasalahan masyarakat tersebut adalah melalui program kewirausahaan. Penentuan kegiatan kewirausahaan ini dilakukan menggunakan pendekatan bottom up, yaitu melibatkan masyarakat secara aktif dalam proses penentuan kebutuhan pembangunan desa setempat. Pendekatan ini memandang bahwa masyarakat merupakan subyek pembangunan, khususnya di kawasan perdesaan. Kegiatan ini mengharapkan tercapainya beberapa target luaran, seperti meningkatkan pengetahuan kewirausahaan, meningkatkan motivasi berwirausaha, serta menumbuhkan kreativitas berwirausaha ibu-ibu PKK. Dengan demikian, pelaksanaan program kewirausahaan diharapkan tidak hanya mampu mengurangi kemiskinan namun juga meningkatkan level sosial masyarakat desa.

\section{METODE PELAKSANAAN}

Pengabdian masyarakat ini diselenggarakan melalui aktivitas penyuluhan dan pelatihan. Kegiatan penyuluhan bertujuan untuk memberikan pengetahuan maupun informasi tambahan kepada peserta terkait materi kewirausahaan dan pembuatan penjor. Sementara itu, kegiatan pelatihan tidak hanya dimaksudkan untuk memberikan ketrampilan agar mampu mencari pekerjaan, namun juga agar mampu menciptakan lapangan pekerjaan bagi masyarakat sekitarnya. Adapun rangkaian kegiatan pelatihan dilakukan melalui empat tahapan, yaitu:

1. Pemerintah dan masyarakat desa mengidentifikasi berbagai permasalahan yang terjadi, menentukan prioritas permasalahan, serta mengusulkan kegiatan-kegiatan yang dianggap mampu menyelesaikan permasalahan tersebut. Penentuan kegiatan juga disesuaikan dengan potensi daerah dan kemampuan masyarakat desa. Berdasarkan hasil diskusi tersebut, kegiatan kewirausahaan yang tepat untuk diaplikasikan pada kedua desa ini adalah pembuatan hiasan penjor.

2. Pelaksana pengabdian melakukan penyuluhan mengenai kewirausahaan dan memberikan pengetahuan tambahan mengenai filosofi dan fungsi penjor.

3. Praktik pembuatan berbagai hiasan penjor. 
4. Pemantauan terhadap tindak lanjut ibu-ibu PKK dalam mempraktikkan pembuatan hiasan penjor secara mandiri maupun berkelompok. Proses pemantauan dilakukan secara berkala selama satu bulan.

\section{HASIL DAN PEMBAHASAN}

\section{Peran Perempuan dalam Perekonomian Keluarga}

Dalam era globalisasi, terjadi pergeseran peran perempuan. Perempuan tidak hanya memiliki peran domestik, namun memiliki peran lainnya seperti peran produksi dan peran sosial (Suyadnya, 2009). Pada awalnya, perempuan diidentikkan dengan peran domestik. Peran ini dimulai ketika perempuan telah memasuki upacara perkawinan. Dalam masa ini, perempuan bertanggungjawab sebagai seorang istri dan ibu yang baik. Peran ini juga menuntut perempuan untuk mampu mengerjakan berbagai pekerjaan rumah tangga (Suryani, 2004). Adanya globalisasi memberikan peluang bagi perempuan untuk menjalankan peran produksi, yaitu memiliki kemampuan untuk menghasilkan uang (Handayani et al., 2017). Dalam hal ini, perempuan tidak hanya membantu suami dalam mencari nafkah, namun juga dapat mengaktualisasikan kemampuan diri dan meningkatkan kepercayaan diri. Peran ketiga, yaitu perempuan memiliki peran sosial dalam masyarakat. Dalam konteks perempuan Bali, peran sosial direalisasikan dalam aktivitas sosial kemasyarakatan di banjar ataupun desa adat, sepeti membantu (ngayah) di pura atau membantu warga banjar atau desa adat lainnya. Status ini diperoleh secara langsung ketika perempuan tersebut menikah dan tinggal di lingkungan desa adat (Suyadnya, 2009).

Dalam upaya untuk meningkatkan kompetensi perempuan, dilakukan program pemberdayaan dalam bentuk pelatihan. Kegiatan ini sekaligus menjadi program pengembangan kapasitas perempuan secara fisik, mental, emosional, dan ekonomi. Selain itu, program ini diharapkan meningkatkan kekuatan dan otoritas perempuan (Lee, 1996) sehingga meningkatkan partisipasi mereka dalam bidang ekonomi. Keterlibatan perempuan juga mendorong proses revitalisasi ekonomi menuju keberlanjutan ekonomi (Dikeocha et al., 2018).

Berkaitan dengan program kewirausahaan berbasis kearifan lokal, perempuan dipandang sebagai pihak yang tepat untuk menggeluti usaha ini. Hal ini dikarenakan jenis kewirausahaan ini sesungguhnya bukanlah aktivitas yang baru atau telah biasa dilakukan. Aktivitas kewirausahaan ini diharapkan tidak banyak menguras waktu dan tenaga perempuan, serta tidak menganggu peran domestik dan sosial perempuan. Dengan demikian, perempuan merasa nyaman ketika menjadi seorang wirausaha. Selain itu, bisnis yang berbasis kearifan lokal meningkatkan peran perempuan dalam upaya pelestarian budaya Bali. Nantinya, budaya ini pun dapat diwariskan secara turun-temurun kepada generasi perempuan lainnya.

\section{Kewirausahaan Berbasis Kearifan Lokal}

Kewirausahaan merupakan konsep yang bersifat multidimensi (Verheul et al., 2002). Secara umum, kewirausahaan didefinisikan sebagai upaya penciptaan atau perluasan usaha (bisnis) yang yang sudah mapan (Levie et al., 2014). Dalam beberapa tahun terakhir, program kewirausahaan dianggap sebagai upaya untuk mengurangi kemiskinan, khususnya 
di negara-negara berkembang (Sutter et al., 2019; Tobias et al., 2013). Kewirausahaan menjadi alat penting untuk membuat kebijakan terkait dengan penciptaan lapangan pekerjaan, sekaligus pengentasan kemiskinan. Pada akhirnya, program kewirausahaan menumbuhkan tingkat perekonomian masyarakat lokal (Gompers et al., 2010).

Salah satu bentuk kewirausahaan yang tepat untuk meningkatkan perekonomian masyarakat desa adalah kewirausahaan berbasis kearifan lokal. Sistem kearifan lokal berasal dari sistem pengetahuan yang ada di lingkungan masyarakat lokal (indigeneus knowledge system), baik empirik maupun pragmatis. Suatu sistem dikatakan memiliki sifat empirik apabila berasal dari fenomena di sekeliling kehidupan masyarakat itu sendiri, dan bersifat pragmatis karena konsep sistem dapat digunakan untuk menyelesaikan permasalahan masyarakat (Adhiputra, 2018). Konsep kewirausahaan berbasis kearifan lokal dianggap tepat karena kearifan lokal sebagai bagian dari kehidupan mereka. Dengan demikian, masyarakat tidak sulit untuk mempelajari, menerima, dan mengakui pengetahuan terkait kearifan lokal.

Adapun program kewirausahaan yang diberikan untuk ibu-ibu PKK adalah pembuatan hiasan penjor. Dalam komunitas masyarakat Hindu di Bali, terdapat dua jenis penjor, yang disebut penjor sakral dan penjor profan (Atmaja, 2008; Pradnyanitasari et al., 2019). Penjor sakral merupakan salah satu sarana upacara keagamaan umat Hindu yang dibuat pada hari raya Galungan dan Kuningan. Secara filosofi, penjor yang terbuat dari tiang bambu tinggi melambangkan Gunung Agung yang menjadi gunung tertinggi di Pulau Bali. Penjor juga merupakan ungkapan terima kasih manusia kepada Tuhan atas anugrah kehidupan dan kemakmuran (Arjawa \& Jayantiari, 2020; Pratama \& Marbun, 2016). Oleh karena itu, penjor dilengkapi berbagai hasil pertanian, seperti plawa, palawija, pala bungkah, pala gantung, serta hiasan yang terbuat dari janur (ental) (Atmadja \& Atmadja, 2016; Pradnyanitasari et al., 2019). Unsur-unsur yang melengkapi penjor tersebut berkaitan dengan simbol atau makna kekuatan Tuhan (Ida Sang Hyang Widhi Wasa). Selain menjadi sarana mengekspresikan rasa syukur dan bakti secara visual, penjor sekaligus melambangkan kerendahan hati manusia dalam proses pencapaian kesuksesan kehidupan (Arjawa \& Jayantiari, 2020).

Jenis penjor lainnya adalah penjor profan, biasanya disebut pepenjoran. Penjor ini tidak digunakan dalam acara keagamaan, namun hanya digunakan sebagai dekorasi menyambut tamu, seperti di hotel, pameran kesenian, ataupun dekorasi pernikahan (Atmaja, 2008). Pada masa lalu, manfaat utama penjor adalah untuk menyambut tamu ketika raja berkunjung ke pedesaan. Saat ini, penjor profan digunakan sebagai dekorasi dalam berbagai acara non keagamaan (Arjawa \& Jayantiari, 2020). Dengan demikian, penjor ini tidak dilengkapi berbagai hasil bumi sebagaimana pada penjor sakral.

Pelaksanaan program kewirausahaan ini diikuti oleh 65 orang ibu-ibu PKK di Desa Kaliakah dan Desa Baluk. Pada tahap awal, peserta mendapatkan penyuluhan mengenai arti penting kewirausahaan dan peran perempuan dalam meningkatkan perekonomian keluarga. Penyuluhan ini bertujuan untuk meningkatkan pengetahuan kewirausahaan, sekaligus memotivasi ibu-ibu PKK untuk berani memulai usaha. Pada kegiatan ini, pelaksana pengabdian juga menyampaikan kembali fungsi atau peran penjor, serta modelmodel hiasan yang biasa digunakan dalam membuat penjor. Kegiatan penyuluhan ini 
dilakukan secara informal mengingat ibu-ibu PKK memiliki latar belakang pendidikan yang bervariasi, yaitu dari lulusan sekolah dasar hingga sarjana. Kegiatan diskusi dan penyuluhan disajikan pada Gambar 1 dan Gambar 2.

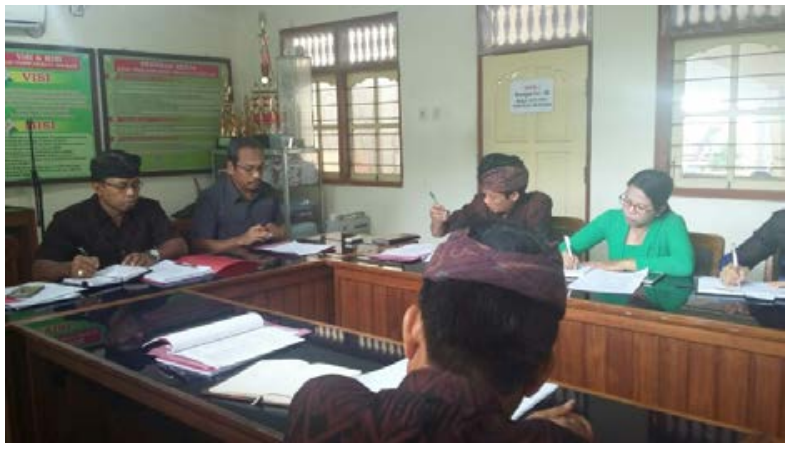

Gambar 1. Diskusi Penentuan Program Kewirausahaan

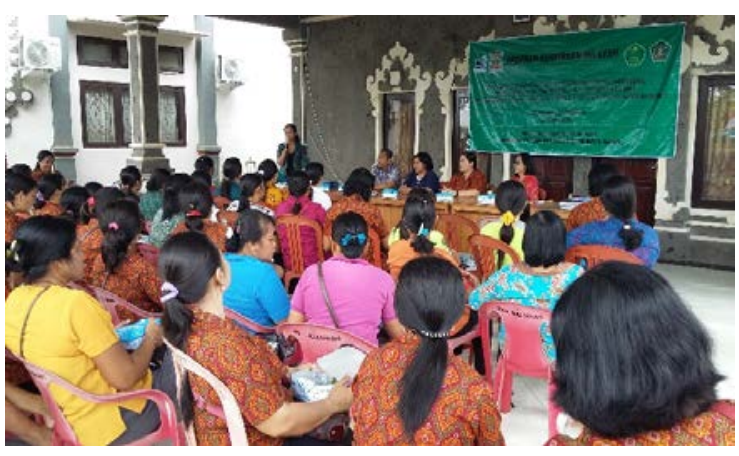

Gambar 2. Penyuluhan Kewirausahaan

Tahap selanjutnya adalah pelatihan pembuatan berbagai model hiasan penjor. Dalam kegiatan pelatihan, pelaksana pengabdian dibantu oleh dua orang instruktur dan dua orang mahasiswa, serta didampingi oleh aparat pemerintah desa. Bahan yang digunakan untuk membuat hiasan penjor adalah ental atau lontar. Saat ini, mayoritas hiasan penjor menggunakan bahan ental karena lebih awet dan mudah diperoleh. Terdapat beraneka ragam bentuk hiasan penjor, seperti kipas, kelopak lidah, bunga, burung, hingga naga. Adapun harga hiasanya penjor sangat bervariasi, biasa dimulai dari sepuluh ribu rupiah hingga mencapai ratusan ribu rupiah. Variasi harga ditentukan oleh ukuran hiasan dan tingkat kerumitan pembuatannya. Menjelang perayaan hari raya Galungan dan Kuningan, masyarakat Bali akan ramai berburu berbagai hiasan penjor. Kondisi ini menjadi peluang usaha bagi ibu-ibu PKK untuk membuka usaha pembuatan hiasan penjor. Pelatihan pembuatan hiasan penjor disajikan pada Gambar 3.
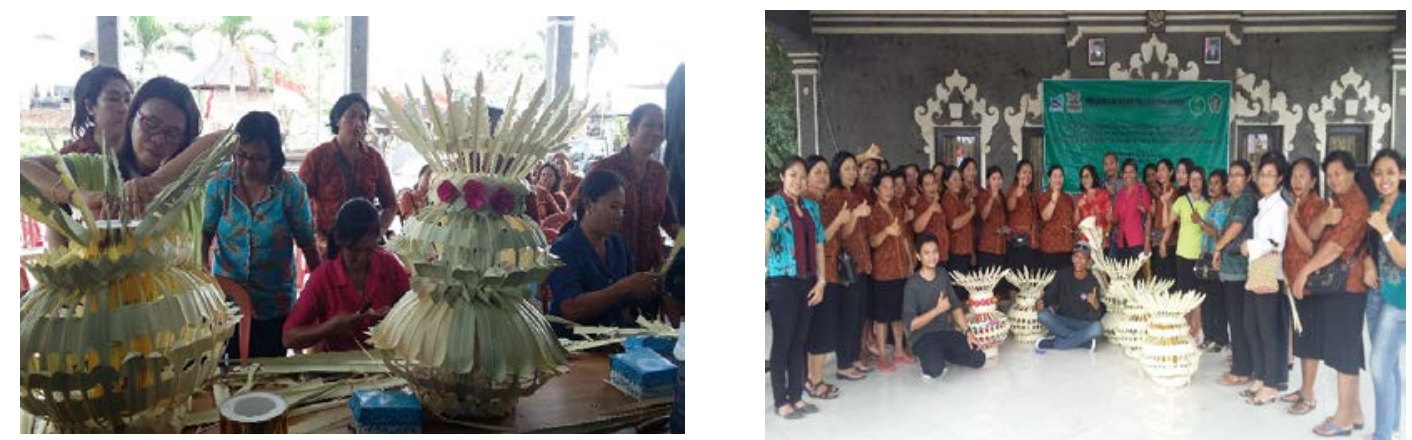

Gambar 3. Pelatihan Pembuatan Hiasan Penjor

Pada akhir kegiatan, tim pelaksana pengabdian melakukan evaluasi kegiatan untuk mengukur pengetahuan dan kompetensi ibu-ibu PKK, serta mengevaluasi efektifitas pelaksanaan program kewirausahaan ini. Hasil evaluasi (post-test) untuk kegiatan penyuluhan menunjukkan bahwa sebagian besar peserta pelatihan (86.46\%) dapat 
menjawab kelima pertanyaan dengan benar. Hal post-test juga menunjukkan bahwa sebesar $83.08 \%$ peserta belum pernah mendapatkan pelatihan mengenai pembuatan hiasan penjor. Berkaitan dengan kegiatan pelatihan, sebagian besar peserta menyatakan bahwa materi kegiatan menarik (90.77\%) dan bermanfaat (84.62\%). Dengan demikian, sebanyak 81.54\% peserta mampu memahami materi pelatihan dengan baik. Dari seluruh peserta pelatihan, sebanyak $61.54 \%$ peserta menyatakan ingin menjadi wirausaha, khususnya berkaitan dengan usaha pembuatan hiasan penjor. Hasil evaluasi kegiatan ditunjukkan pada Gambar 4.
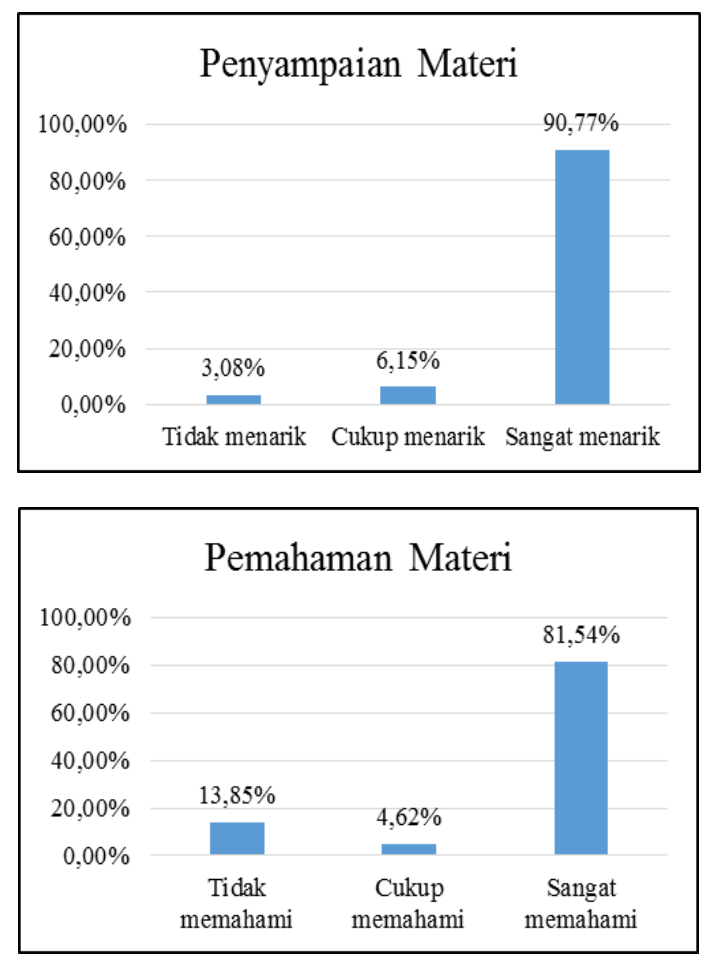
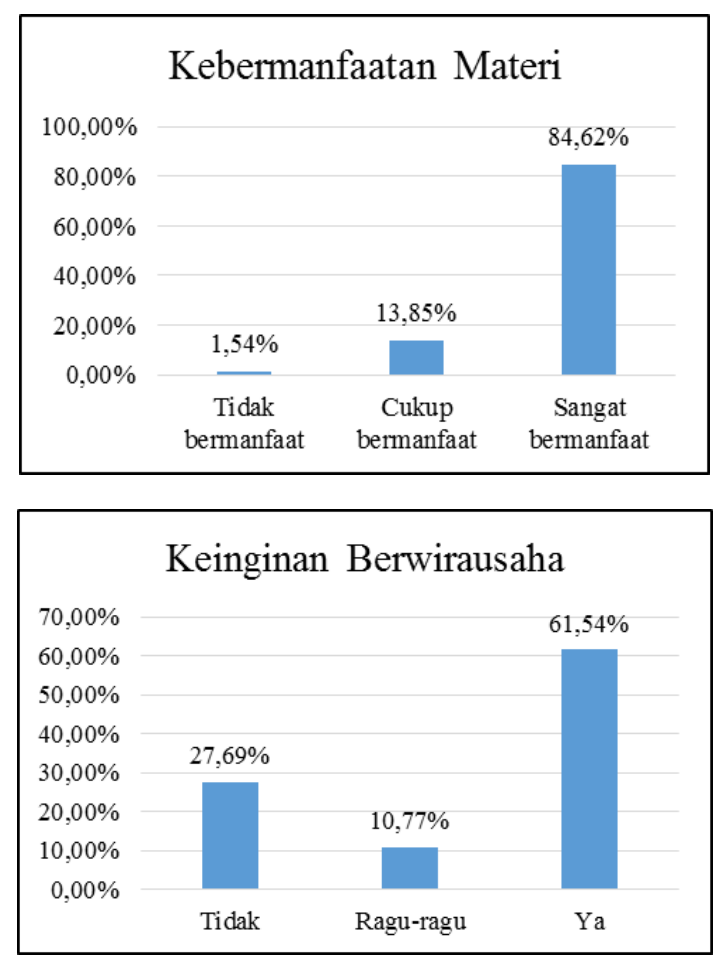

Gambar 4. Hasil Penilaian Evaluasi Kegiatan

Berdasarkan hasil evaluasi kegiatan, terdapat beberapa hal yang harus diperhatikan. Pertama, ibu-ibu PKK menunjukkan rasa antusiasme yang tinggi ketika mengikuti kegiatan penyuluhan dan pelatihan. Hal ini ditunjukkan dari kesediaan ibu-ibu PKK untuk hadir tepat waktu dan berpartisipasi secara aktif dalam praktik "mejejaitan" atau membuat hiasan penjor. Hasil evaluasi kegiatan juga menunjukkan bahwa peserta merespon positif kegiatan yang dilakukan. Meskipun demikian, masih terdapat beberapa peserta yang belum memahami materi pelatihan yang disampaikan. Dalam hal ini, pemerintah desa dan para pelaksana pengabdian harus menindaklanjuti hasil evaluasi ini dengan cara mengintensifkan kegiatan pelatihan, baik secara berkelompok maupun individual. Aktivitas berkelanjutan ini tidak hanya bertujuan untuk meningkatkan pengetahuan ibuibu PKK namun juga meningkatkan kreativitas masyarakat dalam membuat berbagai model hiasan penjor.

Kedua, hasil evaluasi menunjukkan bahwa kegiatan ini mampu meningkatkan motivasi sebagian besar ibu-ibu PKK (61.54\%) untuk menjadi wirausaha. Meskipun 
demikian, beberapa ibu-ibu PKK masih memiliki keraguan (10.77\%), bahkan ada yang tidak tertarik sama sekali (27.69\%) untuk menjadi wirausaha. Kondisi ini menjadi tantangan bagi pemerintah desa dan para pelaksana pengabdian untuk mengembangkan program kewirausahaan lainnya yang tetap memperhatikan potensi desa dan berbasis kearifan lokal. Pemerintah desa juga wajib melaksanakan penyuluhan dan pelatihan secara berkesinambungan sehingga ibu-ibu PKK mampu menjadi perempuan yang produktif, tanpa meninggalkan peran domestik dan peran sosial dalam kehidupan bermasyarakat.

\section{KESIMPULAN}

Kewirausahaan menjadi salah satu program efektif untuk mengurangi kemiskinan. Program ini diimplementasikan melalui aktivitas “mejejaitan" hiasan penjor yang menghasilkan nilai ekonomi tinggi. Kegiatan pengabdian ini dilakukan melalui aktivitas penyuluhan dan pelatihan kepada ibu-ibu PKK di Desa Kaliakah dan Desa Baluk. Kegiatan penyuluhan bertujuan untuk memberikan pengetahuan kewirausahaan sedangkan kegiatan pelatihan dimaksudkan untuk memberikan ketrampilan “mejejaitan” sehingga ibu-ibu PKK mampu menciptakan lapangan pekerjaan. Hasil evaluasi kegiatan menunjukkan bahwa peserta mampu memahami materi dengan baik sehingga meningkatkan motivasi peserta untuk menjadi wirausaha. Meskipun demikian, pemerintah desa perlu melakukan kegiatan permberdayaan secara konsisten dan berkesinambungan agar ibu-ibu PKK mampu menjadi perempuan wirausaha yang produktif dan mandiri.

\section{UCAPAN TERIMA KASIH}

Pelaksana pengabdian mengucapkan terima kasih kepada Kemerinstekdikti yang telah mendanai hibah program kemitraan wilayah, serta masyarakat Desa Kaliakah dan Desa Baluk atas partisipasinya dalam kegiatan pengabdian ini.

\section{DAFTAR PUSTAKA}

Acs, Z. J., Arenius, P., Hay, M., \& Minniti, M. (2005). Global Entrepreneurship Monitor 2004 Executive Report. Babson College and London Business School.

Adhiputra, M. W. (2018). Kewirausahaan mandiri perempuan berbasis kearifan kokal dan filosofi Hindu di Bali. Jurnal Riset Ekonomi Dan Manajemen, 16(2), 237-246. https://doi.org/10.17970/jrem.16.160206.ID

Arjawa, I. G. P. B. S., \& Jayantiari, I. G. A. M. R. (2020). Penjor in Hindu Communities: A symbolic phrases of relations between human to human, to environment, and to God. Masyarakat, Kebudayaan Dan Politik, 33(1), 101-109.

Atmadja, A. T., \& Atmadja, N. B. (2016). Kontestasi penjor Galungan-Kuningan di Bali visualisasi doa petisi secara demonstratif untuk kemakmuran pada era masyarakat tontonan. Jurnal Kajian Bali, 6(2), 159-176.

Atmaja, I. M. N. (2008). Nilai Filosofis Penjor Galungan dan Kuningan. Paramita. 
Bruton, G. D., Ketchen, D. J., \& Ireland, R. D. (2013). Entrepreneurship as a solution to poverty. Journal of Business Venturing, 28(6), 683-689. https://doi.org/10.1016/j.jbusvent.2013.05.002

Carter, S., Kuhl, A., Marlow, S., \& Mwaura, S. (2017). Households as a site of entrepreneurial activity. Foundations and Trends in Entrepreneurship, 13(2), 81190. https://doi.org/10.1561/0300000062

Dhahri, S., \& Omri, A. (2018). Entrepreneurship contribution to the three pillars of sustainable development: What does the evidence really say? World Development, 106(June), 64-77.

Dikeocha, L. U., Nwagu, C. C., Nwaiwu, B. N., \& Ikwugbado, I. (2018). Women emporwerment in entrepreneurship: An effective strategy for poverty reduction. Nigerian Journal of Business Education (NIGJBED), 4(1), 366-372.

Gómez-Gras, J. M., Mira-Solves, I., \& Martinez-Mateo, J. (2010). Determinants of entrepreneurship: an overview. International Journal of Business Environment, 3(1), 1-14. https://doi.org/10.1504/IJBE.2010.031267

Gompers, P., Kovner, A., Lerner, J., \& Scharfstein, D. (2010). Performance persistence in entrepreneurship. Journal of Financial Economics, 96(1), 18-32. https://doi.org/10.1016/j.jfineco.2009.11.001

Handayani, R., Wahyudi, S., \& Suharnomo, S. (2017). The effects of corporate social responsibility on manufacturing industry performance: the mediating role of social collaboration and green innovation. Business: Theory and Practice, 18(August), 152-159. https://doi.org/10.3846/btp.2017.016

Hoang, T. X., Pham, C. S., \& Ulubaşoğlu, M. A. (2014). Non-Farm Activity, Household Expenditure, and Poverty Reduction in Rural Vietnam: 2002-2008. World Development, 64(December), $554-568$. https://doi.org/10.1016/j.worlddev.2014.06.027

Indriani, M. N. (2019). Pemberdayaan perempuan Bali dalam membuat upakara di Banjar Gemeh. Jurnal Sewaka Bhakti, 3(1), 10-24.

Lee, J. (1996). The motivation of women entrepreneurs in Singapore. Women in Management Review, 11(2), 18-29.

Lee, N., \& Rodríguez-Pose, A. (2020). Entrepreneurship and the fight against poverty in US cities. Environment and Planning A: Economy and Space, In Press, 1-22. https://doi.org/10.1177/0308518X20924422

Levie, J., Autio, E., Acs, Z., \& Hart, M. (2014). Global entrepreneurship and institutions: an introduction. Small Business Economics, 42(3), 437-444. https://doi.org/10.1007/s11187-013-9516-6

Peachey, J. W., Burton, L. J., \& Wells, J. E. (2014). Examining the influence of transformational leadership, organizational commitment, job embeddedness, and job search behaviors on turnover intentions in intercollegiate athletics. Leadership and Organization Development Journal, 35(8), 740-755. https://doi.org/10.1108/LODJ10-2012-0128 
Pradnyanitasari, P. D., Priliandani, N. M. I., Juniariani, N. M. R., \& Endra, I. N. (2019). Eksistensi pengerajin hiasan janur dengan strategi cost reduction. JIA (Jurnal Ilmiah Akuntansi), 4(1), 110-123. https://doi.org/10.23887/jia.v4i1.16783

Pratama, K. H. S., \& Marbun, S. (2016). Komodifikasi penjor sebagai sarana persembahyangan umat Hindu. Jurnal Studi Kultural, 1(2), 110-115.

Seuneke, P., Lans, T., \& Wiskerke, J. S. C. (2013). Moving beyond entrepreneurial skills: Key factors driving entrepreneurial learning in multifunctional agriculture. Journal of Rural Studies, 32, 208-219. https://doi.org/10.1016/j.jrurstud.2013.06.001

Suryani, L. K. (2004). Balinese women in a changing society. Journal of the American Academy of Psychoanalysis and Dynamic Psychiatry, 32(1: Special issue), 213-230.

Sutter, C., Bruton, G. D., \& Chen, J. (2019). Entrepreneurship as a solution to extreme poverty: A review and future research directions. Journal of Business Venturing, 34(1), 197-214. https://doi.org/10.1016/j.jbusvent.2018.06.003

Suyadnya, I. W. (2009). Balinese women and identities: Are they trapped in traditions, globalization or both. Diunduh Dari: Http://Journal. Unair. Ac. Id/FilerPDF/01Balinese_Women_and_identities. Pdf.

Thurik, A. R., Carree, M. A., van Stel, A., \& Audretsch, D. B. (2008). Does selfemployment reduce unemployment? Journal of Business Venturing, 23(6), 673-686. https://doi.org/10.1016/j.jbusvent.2008.01.007

Tobias, J. M., Mair, J., \& Barbosa-Leiker, C. (2013). Toward a theory of transformative entrepreneuring: Poverty reduction and conflict resolution in Rwanda's entrepreneurial coffee sector. Journal of Business Venturing, 28(6), 728-742. https://doi.org/10.1016/j.jbusvent.2013.03.003

Verheul, I., Wennekers, S., Audretsch, D., \& Thurik, R. (2002). An eclectic theory of entrepreneurship: policies, institutions and culture. In Entrepreneurship: Determinants and policy in a European-US comparison (pp. 11-81). Springer. 